\title{
Overview of karst in Rembang and Blora: their prehistoric cave settlement potential
}

\section{Hari Wibowo and Indah Asikin Nurani}

Regional Agency for Archaeological Research in D.I. Yogyakarta Province, Jl. Gedongkuning No. 174, Yogyakarta 55171

\begin{abstract}
Despite the potential of the Rembang zone mountain range is meagre compared to the Kendeng mountain range situated to the south, the Rembang Zone is still known to have archaeological potential. Research in the Rembang Zone in Blora and Rembang regencies have been conducted since 2005. This study aims to reveal the potential for prehistoric cave occupations in the two regencies, which are influenced by karst morphology and lithology. The biggest impact of the morphology and lithology is the lack of caves, rock shelters, or the formation of collapsed doline, which are adequate as prehistoric cave dwellings.
\end{abstract}

Keywords: prehistoric settlement, archaeology, dwelling caves, Rembang, Blora 


\section{INTRODUCTION}

Rembang and Blora regencies are part of the karst area in the mountains of the northern part of Java, an area that van Bemmelen calls the Rembang Zone (van Bemmelen, 1949). The Rembang Zone, often referred to as the North karst mountain range, stretches parallel to the Kendeng mountain range, where it is separated by the Randublatung Zone. The Rembang Zone is a fault zone between a carbonate exposure in the north (Java Sea) and a deeper basin in the south (Kendeng Zone). The constituent lithology is a mixture of shallow marine carbonates with clasts, as well as deep sea clays and marl.

Archaeological research on the karst area of the Blora Regency shows that most of the caves are unfit for habitation. In 2005, an archaeological survey was conducted in 17 caves, of which only one doline contained two caves. This gives an indication of its high archaeological potential, namely the Kidang Doline (Figure 2). Most of the types of caves in the Blora karst area are underground rivers, vertical caves, and hillside caves, which are unfit for habitation (Nurani and Yuwono, 2008). Furthermore, from 2009 to 2018, the Kidang Doline was excavated with surprising results, namely three individuals of Homo sapiens skeleton. These were found in different stratigraphic positions and locations within the cave. In addition, the findings of human life traces as cave dwellers were in the form of food scraps (flora-fauna) and various types of shell and bone artifacts. The dominant amount of shell and bone artifacts indicate a significant difference in the culture of prehistoric cave dwellings, especially in Java (Gunung Sewu), while lithic fragments are almost absent (Nurani et al., 2019).

Based on the results of research done in the Blora karst area, exploring the northern karst area in the Rembang Regency is still a fascinating choice despite the number of prehistoric caves. In 2019, survey results in the Rembang Regency produced several cave clusters (Wibowo et al., 2020). Archaeological surveys results have shown 51 caves consisting of vertical

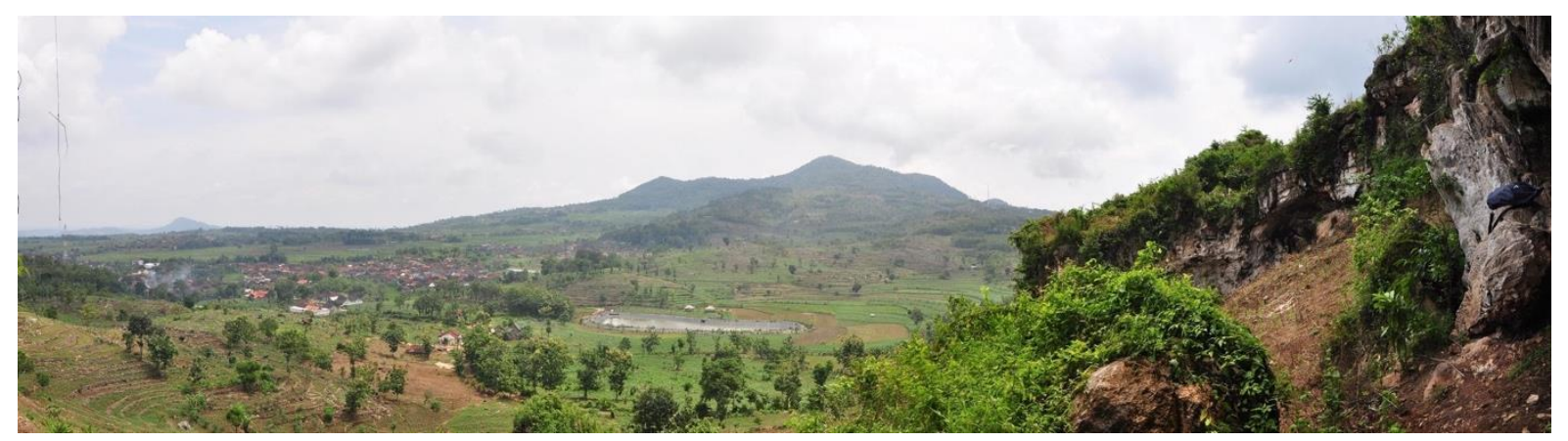

Figure 1. Landscape of Rembang Zone karst hills in the Rembang Regency (Source: documentation of the Regional Agency for Archaeological Research in D.I. Yogyakarta Province). 


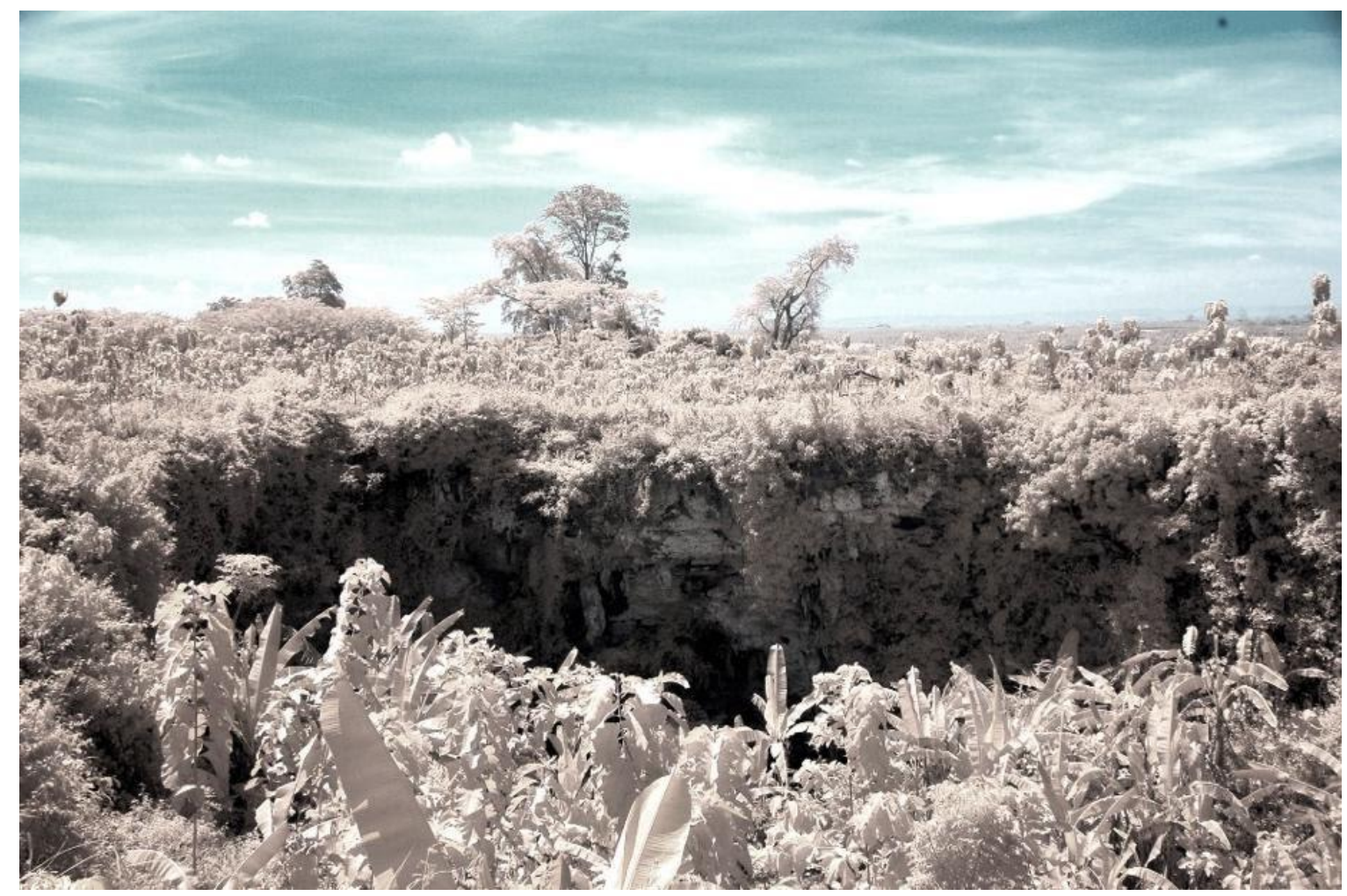

Figure 2. Collapse doline Kidang, Blora Karst (Source: documentation of the Regional Agency for Archaeological Research in D.I. Yogyakarta Province).

caves, horizontal caves, inlets, and collapse doline. Based on the total number of caves surveyed, it is known that there are three caves that indicate a prehistoric dwelling cave. Even so, the three caves that are considered habitable still need to be proven by archaeological excavations (Wibowo et al., 2019). The survey results showed that archaeological potential of Rembang Zone karst area in the Rembang Regency as a prehistoric settlement cave, is very low when compared to the karst segments of the Kendeng mountain range at the south (Figure 3).

\section{METHODOLOGY}

This study uses survey and archaeological excavation methods to collect data. Data from Rembang was obtained through a survey conducted in 2019. The data from Blora were obtained through a survey conducted in 2005-2006 as well as excavations conducted from 2009 to 2018. Data from these two research areas were synthesized to see the effect of the karst environment on possible prehistoric settlements in the caves. Data from the Southern Mountains of Java, especially Gunung Sewu Area, were obtained through literature studies that were used as a comparison because there are evidence 
for its great potential as a prehistoric dwelling cave.

\section{RESULTS}

Based on the comparison between lithology to formation characteristics in the regional stratigraphy of the Rembang Zone, the Rembang Zone stratigraphy from the lower (old) to the top (young) layers is divided into several formations, namely Tawun Formation, Ngrayong Members of Tawun Formation, Bulu Formation, Wonocolo Formation, Ledok Formation, Mundu Formation, and Solo Terraces Alluvium Deposits. In regard to the formation of these formations, and also based on research in Rembang and Blora regencies, archaeological caves were found in the lithology of the Bulu
Formation from Middle Miocene to Late Miocene (Nurani et al., 2019; Pringgoprawiro, 1983). In the Rembang Regency, the cave clusters that are thought to have high archaeological potential are in the southern part as well as in the Bulu Formation, which stretches from the Gunem Regency to the Bulu Regency (Wibowo et al., 2019). In addition, Bulu Formation hosts the only cave that is proven to have archaeological potential in the Blora Regency, namely Kidang Cave (Nurani, 2011).

The karst areas of Blora and Rembang regencies show that the limestone of Bulu Formation is the most suitable for creating caves as a prehistoric residential location. For instance, other limestone lithologies such as the Paciran Formation, form many vertical

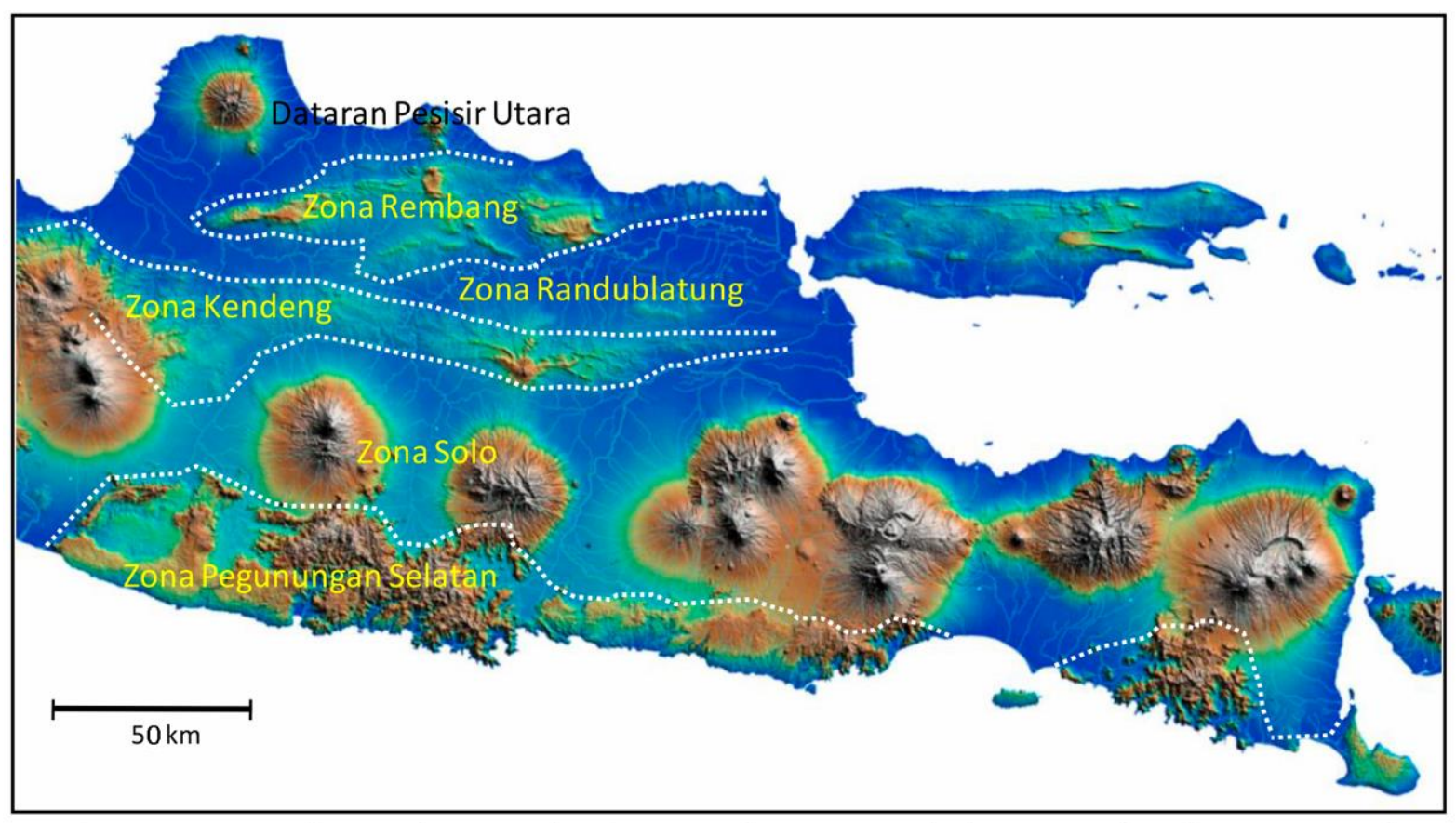

Figure 3. The regional physiographic zoning of central and eastern Java Island (division follows Pannekoek, 1949; van Bemmelen, 1949) (Source: Husein, 2016). 


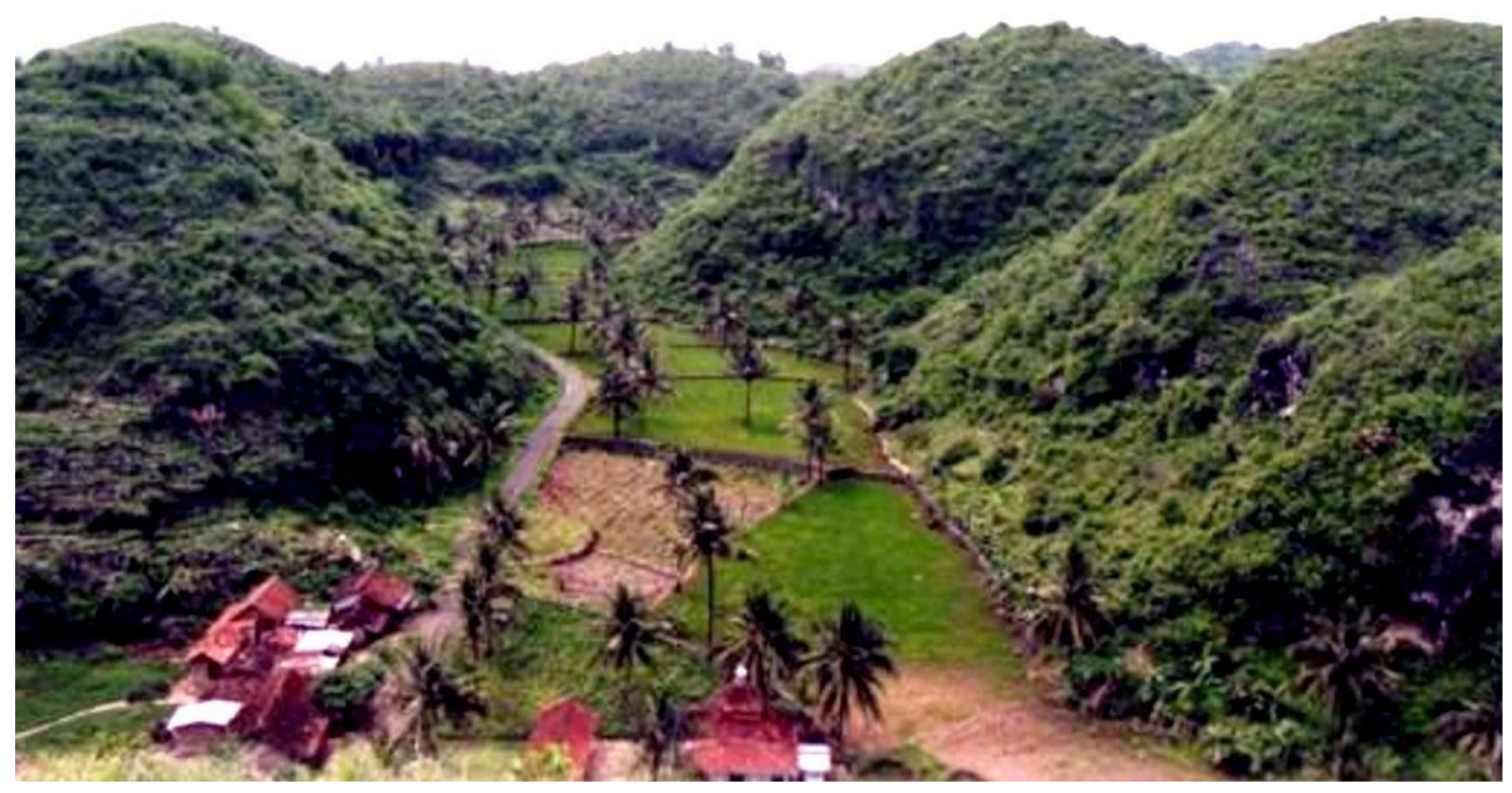

Figure 4. Mount Sewu Karst Area with conical hills (Source: Haryono et al., 2016).

caves that were uninhabitable by prehistoric humans. The lithology of the Bulu Formation is known to form rock shelters and collapse doline, which has potential as prehistoric dwellings in these two regencies. However, in terms of quantity, there are not many caves and rock shelters that has the potential to be inhabited in the two regencies. One of the factors causing the lack of habitable caves, rock shelters, or collapse doline is the morphology of the karst in these two regencies. The morphology of the karst area generally lies in a folded hill structure. After the folding undergoes a dissolving process, the morphology of conical hills was formed at the top surface of the karst hills (exokarst). In other parts of the landscape, dissolved basins (doline) were then formed. River stream valleys form the mouth of the cave (sinkhole), and water and lake karst were found at the bottom (Wacana et al., 2014). Meanwhile, there are minimal conical hills in these two regencies. This shows that the karstification process in this area is yet to be perfect (Figure 4).

The morphology of the Rembang Zone is generally less sloping and more symmetrical than that of the Kendeng mountain range, which are steeper (Nurani and Yuwono, 2008). Furthermore, observation of the landscape around the Kidang Cave shows landscapes with a flat morphology in the Blora Regency (Nurani et al., 2019). Karstification occurs due to weathering, erosion, and denudation processes which then produce rough and steep topographic and morphological expressions. The 
relatively gentle slope morphology and the lack of conical hills indicate that the karstification level in the Rembang Zone in Blora and Rembang is younger than the karstification process in the Southern Mountains of Java (Nurani et al., 2019). In the Rembang Zone, it is estimated that the karstification process occurred during the Middle Miocene, which was caused by uplift due to tectonic activities and the drop of sea level that occurred at that time (Nurani et al., 2019). When compared to the karstification in the Southern Mountains of Java, specifically in Gunung Sewu, the karstification process has occurred since the Lower Miocene (Intan and Simanjuntak, 2002).

\section{CONCLUSION}

Morphological aspects appear to be the main controlling factor for the lack of potential for archaeological prehistoric settlement in the karst area of the Rembang Zone in Rembang and Blora regencies. The availability of caves for inhabitation is minimal, forcing prehistoric humans to live in one place for long periods of time. This is confirmed by the results of research in the Kidang Cave in Blora, which was inhabited for a long period since the Late Pleistocene. In fact, the results of the latest excavation study (reaching a depth of $225 \mathrm{~cm}$ from the surface) have not shown the end of the cultural layer. Signs of cave inhabitation in Kidang Cave are still present, and the sterile layer of culture is not yet reached.

Another possibility is that the inhabitants of the karst areas of
Rembang and Blora in prehistoric times are more oriented towards open areas. If this assumption is accepted, then the chances of finding the remains of prehistoric culture are most likely around the locations of ancient springs or river streams in the area. This open area around the water source is more likely to contain settlement potential.

\section{ACKNOWLEDGEMENTS}

All research covered in this paper is funded by the Ministry of Education and Culture through the Regional Agency for Archaeological Research in D.I. Yogyakarta Province. The authors would like to thank all those who have helped this research from the start of the research in 2005 to 2019.

\section{REFERENCES}

Haryono, E., Widartono, B. S., Lukito, H. and Kusumayuda, S. B., 2016. A comparison of lineament and fracture trace extraction from LANDSAT ETM+ panchromatic band and panchromatic aerial photograph in Gunungsewu karst area, Java-Indonesia. IOP Conference Series: Earth and Environmental Science, 47(1).

https://doi.org/10.1088/1755$\underline{1315 / 47 / 1 / 012026}$

Husein, S., 2016. Fieldtrip Geologi Cekungan Jawa Timur Utara. PT. Geodwipa Teknika Nusantara. https://www.researchgate.net/public ation/315486479_Fieldtrip_Geologi_C ekungan_Jawa_Timur_Utara/stats 
Intan, F. S. and Simanjuntak, T., 2002. History of the Formation of Gunung Sewu and the Karst Caves. In: T. Simanjuntak (Ed.), Gunung Sewu in Prehistoric Times (hal. 49). Gadjah Mada University Press.

Nurani, I. A., 2011. Penghuni Gua Kidang: Penjelajah Tangguh Di Kawasan Karst Blora. Berkala Arkeologi, 31(2), 107-121.

\section{https://doi.org/10.30883/jba.v31i2.3} $\underline{89}$

Nurani, I. A., Hascaryo, A. T., Koesbardiati, T., Murti, D. B., Wibowo, H. and Aries, F. R., 2019. Okupasi Dolina Kidang Hunian Prasejarah Akhir Plestosen - Awal Holosen Kawasan Karst Blora (Y. Zaim (ed.)). Balai Arkeologi Daerah Istimewa Yogyakarta.

Nurani, I. A. and Yuwono, J. S. E., 2008. Gua Kidang, Pilihan Manusia Prasejarah Di Kawasan Karst Blora. Berkala Arkeologi, 28(1), 1-20.

\section{https://doi.org/10.30883/jba.v28i1.3}

$\underline{51}$

Nurani, I. A., Zaim, Y., Setiawan, P., Wibowo, H., and Sulistyarto, P. H., 2019. LPA Setting Okupasi di Situssitus Kala Pleistosen - Awal Holosen Kawasan Gunung Sewu, Kabupaten Pacitan.

Pannekoek, A. J., 1949. Outline of The Geomorphology of Java (Vol. LXVI). Koninklijk Nederlands Aardrijkskundig Genootschap.
Pringgoprawiro, $\quad$ H., 1983. Biostratigrafi dan Paleogeografi Cekungan Jawa Timur Utara: Suatu Pendekatan Baru. Institut Teknologi Bandung.

van Bemmelen, R. W., 1949. The Geology of Indonesia. Vol. 1A. General Geology of Indonesia and Adjacent Archipelagoes. Martinus Nijhoff.

Wacana, P., Rodhialfalah, A., Widjanarko, S., Chandra, F., Ahmad, F., Fauzi, I. and Lukiarti, M., 2014. Kajian Potensi Kawasan Karst Kendeng Utara Pegunungan Rembang Madura Kabupaten Rembang , Abstrak Latar Belakang Fisiografi dan Morfologi Geologi. Prosiding Seminar Nasional Kebumian Ke-7, 30-31.

Wibowo, H., Yuwono, J. S. E. and Nurani, I. A., 2020. Pengaruh Morfologi dan Litologi Kawasan Karst Kabupaten Rembang Terhadap Potensi Hunian Gua Prasejarah. Naditira Widya, 14(1), 1-18.

https://doi.org/10.24832/nw.v14i1.4 04

Wibowo, H., Yuwono, J. S. E., Nurani, I. A., Riyanto, S., Harimurti, W. A., Pratama, H. R., Saputro, B. I., Yuniawan, A. A., Wicaksono, G., Fadhlurrohman, N., Riyani, N. E., Sadiman and Purnama, F. B. J., 2019. Potensi Gua Kawasan Karst Zona Rembang Di Jawa Sebagai Hunian Prasejarah. 